\title{
Research on Institutions Salary Management System
}

\author{
Hongjuan Gao ${ }^{1}$
}

${ }^{1}$ Tianjin Finance and Economics University, Tianjin, 300000

KEYWORDS: Institutions, Salary Management System

\begin{abstract}
According to the requirements of the national and provincial institutions reform, restructuring of public institutions into enterprises have been included in the agenda, its compensation management is increasingly becoming an important area of economic management scholars and academics concerned. According to the review on the reform process and status quo analysis about institutions salary management, the paper points out the shortcomings of institutions in compensation management. Through the use of economics, management science and other theoretical tools, combined with compensation system for public institutions to analyze the problems proposed in compensation management mechanism.
\end{abstract}

\section{Introduction}

In the spirit of National Congress Party and the Thought of "Three Represents" as guidance, implement the requirements of the national and provincial reform of public institutions, in accordance with the "decoupling, classification, conversion, invigorate the" principle, the institutions have to market is inevitable. Institutions into enterprises in the same time, implementation of the reform of property rights, competitive fields should be complete withdrawal of state-owned assets in principle, if not a one-time withdrawal, no longer holding. In compensation management as a starting point, transition institutions management system and operation mechanism and it is to accelerate the transformation into enterprises approach.

Salary Policy of organs and institutions is accompanied by the planned economy gradually transition to a market economy in. Salary System Reform in 1993 the largest previous reform efforts, first, authorities and institutions separate salary system, the establishment of a compensation system in line with their own characteristics. Institutions of professional and technical personnel according to five categories of different industries, the establishment of professional and technical positions grade wage system, the establishment of a management staff job classification wage system, wages fixed by the wage and live parts. The second is to establish a mechanism for regular pay for promotion. The third is the establishment of a wage dynamic adjustment mechanism. The pay system has played an important role in the management of public institutions. At the same time, we should see that the compensation theory, the practice has developed rapidly in the past 10 years, the traditional wage theory has not well adapted to changes in institutions of internal and external environment. At the same time, the drawbacks of conventional institutions pay system gradually highlights, such as the salary adjustment lever reverse, less the value of a single human capital, knowledge workers compensation rising path compensation, egalitarianism, ignoring issues such as internal compensation allocation.

21st century is the era of knowledge economy, human capital has replaced the industrial age "capital" has become today's most important strategic resource. For the institutions concerned, to 
attract and retain talent is to ensure competition in the market. With modern human resources management concept in depth, we realized that the staff should be seen as a carrier of human capital, focusing on the needs of employees of self-realization, with the basic ideas and methods of modern human resources management for staff management, motivation and development.

\section{The Current Situation of Institution Salary System}

At present, decision-making and management of our institutions are highly centralized pay system, formulated by the state, all institutions comply. Since institutions exist in various industries, and many types, so many institutions of the remuneration system, including: the wage system wage system of professional and technical personnel, the wage system managers and workers. Where the wage system of professional and technical staff and include: professional and technical positions grade wage system, professional and technical posts in wage, Art structural wage system, sports allowance, bonus system, the pilot level wage system.

Institutions management staff, according to their characteristics, on the basis of the establishment of the staff positions of a sequence, implement wage level staff positions. Staff job level wage system wage structure, divided into staff positions wages and job target management allowances in two parts. Staff wages based on job duties is based on the level of employees, the size and difficulty of the job responsibilities determined wage, rank wage system is embodied in an important part of distribution according to work. In wage job, each job has a number of salary grade level and position held by the employee to determine the appropriate wage job, and with the duties and tenure of changes. Remuneration system and institutions implement the principle of distribution according to work, wages and salaries of employees of state-owned enterprises staff quite flat.

In addition to the remuneration of external, public sector employees also have some inherent remuneration, remuneration inherent produced in the work itself, which refers to the staff as the work itself is a commodity or consumer goods. Since the occupation is often the main criterion for a measure of people's economic and social status of people, including in remuneration, no doubt, that of "excellent learning Shi" Impact and institutions and their employees to apply administrative level realities of public sector employee internal pay is very high.

\section{The Theoretical Basis of Compensation Management}

Human capital theory. Human Capital Property Rights, refers both to the rights of human capital owners use human capital in social production and business activities, but also refers to the sum of human capital owner in accordance with the law and the exercise of the rights of the respective code of conduct. As a special form of capital, human capital property has three distinct characteristics: first, the natural human capital attributable to individual; secondly, human capital property rights, once damaged, its assets may be devalued or gone immediately; s Third, spontaneous human capital always seeks to achieve self-market.

Through the above analysis, we can see that companies only recognize human capital ownership, protection of property rights of human capital from damage, in order to make the value of human capital to be fully realized, so that enterprises continue to add value physical capital. And to try to meet the requirements of equitable remuneration of human capital, so that human capital owners share residual claim is an effective way to achieve this goal.

Principal-Agent Theory. Principal-agent theory is an important part of the economics of information and it is used to describe an economic theory under conditions of asymmetric information between the principal and agent. In modern society, the vast majority of companies 
have implemented the separation of ownership and management. Asset owner assets entrusted to an operator under the conditions previously agreed management, ownership remains all donors and investors enjoy the residual claim by the proportion of investment and ultimate control. Operators within the range authorized by the principal, according to the rules of corporate assets of the enterprise systems possession exercise, control over the use and disposal rights, and obtained from the principal paid. Principal and agent contract previously reached by the parties of the responsibilities, rights and interests clearly defined, thereby forming a mutual restraint, mutual encouragement of contractual arrangements.

Efficiency Wage Theory. Wages are the main part of the cost of doing business. New ideas efficiency wage theory is that pay higher wages may be advantageous, because of the high wages can improve the efficiency of enterprise workers and reduce employee turnover. According to the theory of neoclassical economics, wages determined by the marginal productivity of workers, but the development economists in empirical research we found that in some developing countries, on the contrary - "marginal productivity depends on the wage." Subsequently it was found that the "marginal productivity depends on the wage" phenomenon also exists in developed countries, especially the wages paid by enterprises above the reservation wage workers market phenomenon and neoclassical theory predictions do not match.

\section{The Problems of Compensation Management in Institutions}

It will not pay as a lever to achieve organizational strategy. Traditional compensation theory, in particular, are only interested in direct financial reward money wages, because, according to classical economic theory, the pay is the cost of labor is a cost of production; at the same time, the remuneration is to motivate employees to work hard in the most important source of power. Correspondingly, the traditional management theory will reward the most unique employee incentives. Although the salary management theory has developed rapidly, but as compensation philosophy of market competitors and institutions has stalled - "on the wages ", salaries did not play to achieve organizational strategies as leverage.

Remuneration lever has a reverse adjustment feature. Chinese traditional "not scarcity and uneven distribution," thinking, reflected in the reward is equally distributed. Egalitarianism leads to serious discrepancies on the compensation strategy. Problems institutions within the egalitarian distribution have not been resolved. Since the founding of every major reform of the wage system is breaking down around this goal of egalitarianism. In the low-wage institution is distributed equally low level; the high wages of high-level institutions are evenly distributed. Thus, institutions have in fact reverse lever salary adjustment feature: the low quality of staff salaries above the market average in total compensation in certain circumstances, pay a higher quality of the staff is below the market average.

Remuneration package in the proportion of performance pay is too low. Pay for performance is more popular in recent years, Western management remuneration scheme refers to employee performance-related incentives to improve their performance pay programs, a broad sense, it includes all the work of performance-related pay in addition to the project based remuneration. In nature, performance pay program is a salary management system of the organization, but also organizational design incentive pay program.

In compensation management institutions, there is a considerable degree of "pay harden" phenomenon, namely salaries, although base salaries, bonuses, benefits and allowances and other project components, but in actual operation, but not be distinguished. The main reason is the characteristics of the remuneration of the four components of understanding are not deep enough. 


\section{Optimization Strategies of Institutions Salary Management}

Strengthening pays leverage organizational implementation of the strategy. American scholar Thomas Wilson in "Remuneration Framework" in his book pay not just for recognition or reward employee contributions, it is a set of the company's strategic goals and values into concrete action programs, as well as support staff to implement management process of these actions. Up and down which can form a uniform situation within the company. Compensation system is concerned that actions and their outcomes. It includes wage plan, incentive bonuses and approaches, as well as various forms of recognition for individual contribution scheme.

Remuneration gradually makes the necessary strategic framework. Compensation strategy is based on the top management of the proposed approach, which emphasizes relative to the same scale competitive enterprises, and the differences in their standard salary payments. We can see from the definition can, compensation strategy includes two-pronged strategy, corporate strategy reflects one payment standard that pay level strategy; second is to reflect the business strategy of the payment standard, namely salary structure policy. Pay level policy is essentially external competitiveness strategy enterprises pay and its essence is to set up a strong company optimal compensation levels established in the market pay levels. Enterprises according to different pay policy objectives set at the salary levels higher than, the equivalent and below market levels.

Moderate increase in performance pays remuneration package of proportion. Introduced in the existing institution salary management performance pay concept, by adjusting the merit and performance deterioration of the income of employees, employee psychology - behavior of mutual regulation to stimulate employee behavior, so as to achieve its potential purpose can give full play to pay incentives. Type of pay for performance can be distinguished according to the different employee groups, generally divided into front-line staff, managers, marketing personnel and other categories. Performance pay different categories of employees are not the same.

In the performance appraisal is an important part of the theoretical performance pay remuneration to change. Interface PAS poor institutions and remuneration system, employees will result largely theoretical pay and performance pay on the other, thereby reducing the incentive pay. In general, the basic salary for staff salaries theory, theory combined remuneration of examination results obtained compensation for the performance appraisal salaries. Currently there are certain problems in public institutions and the use of performance evaluation efforts to respect the results. From the viewpoint of the use of force evaluation results further highlight the value of an independent assessment to ensure that all levels of assessment more attention.

\section{Conclusion}

Institutions transformed into enterprises in the process, you can pay the full leverage of its organizational strategy implementation. Thinking pay system design issues from compensation strategy and strategic business perspective matching. In this process, the different stages in which the combined organization (tissue growth stage, mature stage of the organization, organizational recession), different pay strategies. Enlightenment wisdom of our modern human resource management, to enhance its core competencies, compensation management microscopic units can and must reflect some strategic.

\section{Reference:}

[1] Cheng Siwei 46. Problems faced by Chinese enterprise management. Democracy and Construction Press, 1999 
[2] Wang Wei. On the transfer of management resources in the enterprise group. China Soft Science, 1999 (5)

[3] Zhang Xiaolin Organizational Citizenship Behavior Theory and Research. Psychology, 2000 (l)

[4] IJ Hung Wen, Zhao Shuming. Determining Entrepreneurs' Compensation principles, factors and programs. China Soft Science, 2000 (6)

[5] Huang Qun-hui. Senior managers incentive and restrictive mechanism Summary of Symposium. China Industrial Undertakings, 1998 (12) 